\title{
Factors affecting on propagation and production of clove bean [Ipomoea muricata (L.) Jacg.]; an underutilized vegetable crop in Sri Lanka
}

\author{
S. Y. Munasinghe and K. M. C. Fernando* \\ Department of Crop Science, Faculty of Agriculture, University of Ruhuna, Mapalana, \\ Kamburupitiya, Sri Lanka.
}

\begin{abstract}
Clove bean (Ipomoea muricata) is one of the neglected and underutilized vegetable crops available in Sri Lanka. Three experiments in the present study were conducted to find out (1) the best storage period and condition for the clove bean seeds, (2) the effect of the number of nodes and the leves on rooting of cuttings and (3) the suitable potting mixture and fertilizer type for growth and yield of clove bean. The first, second and third experiments were set up as two factor factorial completely randomized design, simple completely randomized design and two factor factorial randomized completely block design, respectively. The interaction effect between storage period and storage condition on final germination percentage and germination rate index was not significant. However, final germination percentage and germination rate index were significantly affected only by storage conditions where seeds stored under room temperature showed greater performances. The number of roots, total root length, vigour scale for roots and bud growth were not significantly different among cuttings with single or double nodes and presence or absence of full leaf or half leaf. The interaction effect between potting mixture and fertilizer type was not significant for measured parameters. However, the number of pods per vine, fresh and dry weight of edible portion and total aboveground dry biomass vary with the potting mixture and fertilizer type. The highest values were recorded in potting mixture prepared by topsoil: sand: compost, 1:1:1 and organic fertilizer treated plants. Fresh and dry weight of non-edible portion was significantly influenced by potting mixture and fertilizer type, respectively. Root dry weight and shoot to root ratio were not significantly influenced by the treatment. According to the results of the three experiments, it can be concluded that seeds of the clove bean can store for two months under room temperature without significant loss of germination. Furthermore, the number of nodes and presence or absence of leaf or half leaf did not influence the rooting of cuttings. High growth and yield of clove bean could be achieved when growing plants in the potting mixture prepared by topsoil: sand: compost 1:1:1 and supplied with organic fertilizer.
\end{abstract}

Keywords: Clove bean, Fertilizer type, Potting mixture, Seed germination, Vegetative propagation

\section{INTRODUCTION}

The extremely high global population in the recent past has created an extra weight on the global agricultural resources (Abdulkadyrova et al., 2016). Rapid population growth, a real threat to wellbeing of the people living in poor countries, urges the production of food worldwide (Ezeh et al., 2012). However, fulfilling the requirement of food demand of the growing population is a huge challenge (Cui and Shoemaker, 2018). As a result of a food shortage, hunger and malnutrition issues may arise. The distress that occurred due to lack of food defines as hunger. Malnutrition defines as a condition of the results of receiving quality and quantity of food inadequately (WeisfeldAdams and Andrzejewski, 2008). Many people living in developing countries are affected by the malnutrition and hunger
*Corresponding author: menaka@crop.ruh.ac.lk Received: 01.06.2021 https://orcid.org/0000-0002-6130-7669 Accepted: 10.09.2021 
crisis, which results from the death of 3.1 million children annually (Wallace et al., 2010). Major components of a balanced human diet are vegetables and fruits though their consumption is relatively low worldwide. However, there is a negative association between consumption of vegetables, fruits and other plant based products with the occurrence of chronic diseases (Bursać Kovačević et al., 2020). Some malnutrition-related concerns can be addressed by incorporating fruits and vegetables grew wild into human diet (Bvenura and Sivakumar, 2017). Underutilized vegetables define as vegetables that are neither grown commercially and nor broadly trade.

The underutilized vegetable can provide micronutrients to the diet by diversifying the ingredients of the diet. On the other hand, underutilized vegetables open an avenue for a balanced diet, especially for the rural poor. Most of the underutilized vegetables are rich in vitamins, minerals and antioxidants. In addition to that, underutilized crops have plenty of therapeutic and medicinal value. They have adapted to a wide range of environments and contribute massively to the agroecosystems functions. Therefore, the contribution of underutilized crops on global food security to meet new market demands is significant (Jena, 2018).

Clove bean (Ipomoea muricata) belongs to the family Convolvulaceae, a well-known vegetable in India (Parisa et al., 2019). Clove bean has herbaceous stem rich in minute speculate protuberances which emerge from the epidermis of the stem. It has pseudo fruit or hypocarp produced by fleshy enlargement of the peduncle/pedicel while the true fruit is a capsule. Purple colour funnel shaped flowers bloom in the evening. Leaves are smooth, soft and cordate in shape, the lobes are rounded and the apex tapers into a short caudex (Parisa et al., 2019).

Two to four black colour glabrous shape seeds can be found in a single capsule (Plate 1). According to the results of the study of 25 accessions of clove bean in Kerala, India, Malasawmkimi and Markose (2008) found that on average protein, phosphorous, iron, calcium and ascorbic acid content $(\mathrm{mg} / 100)$ of the fruit is 1.25 , $130,0.16,210$ and 36, respectively. The crude fibre content of the fruit is around $1.9 \%$. Clove bean seeds, leaves and stems are used to treat chronic wounds and blisters of burn of skin (Malasawmkimi and Markose, 2008).

Clove bean is one of the neglected and underutilized vegetables that received less attention in Sri Lanka, despite its nutritional, medicinal and therapeutic values. Further, the production and demand for clove bean are low due to a lack of awareness of the crop and planting materials. Therefore it is vital to protect and conserve clove bean for future generations.

The available literature on vegetative propagation, growth and yield on clove bean is limited. Therefore, the present study was conducted to identify the best storage period and condition for storing seeds, the best cutting type for vegetative propagation and the suitable potting mixture and fertilizer type for growth and yield of clove bean in Sri Lanka. 


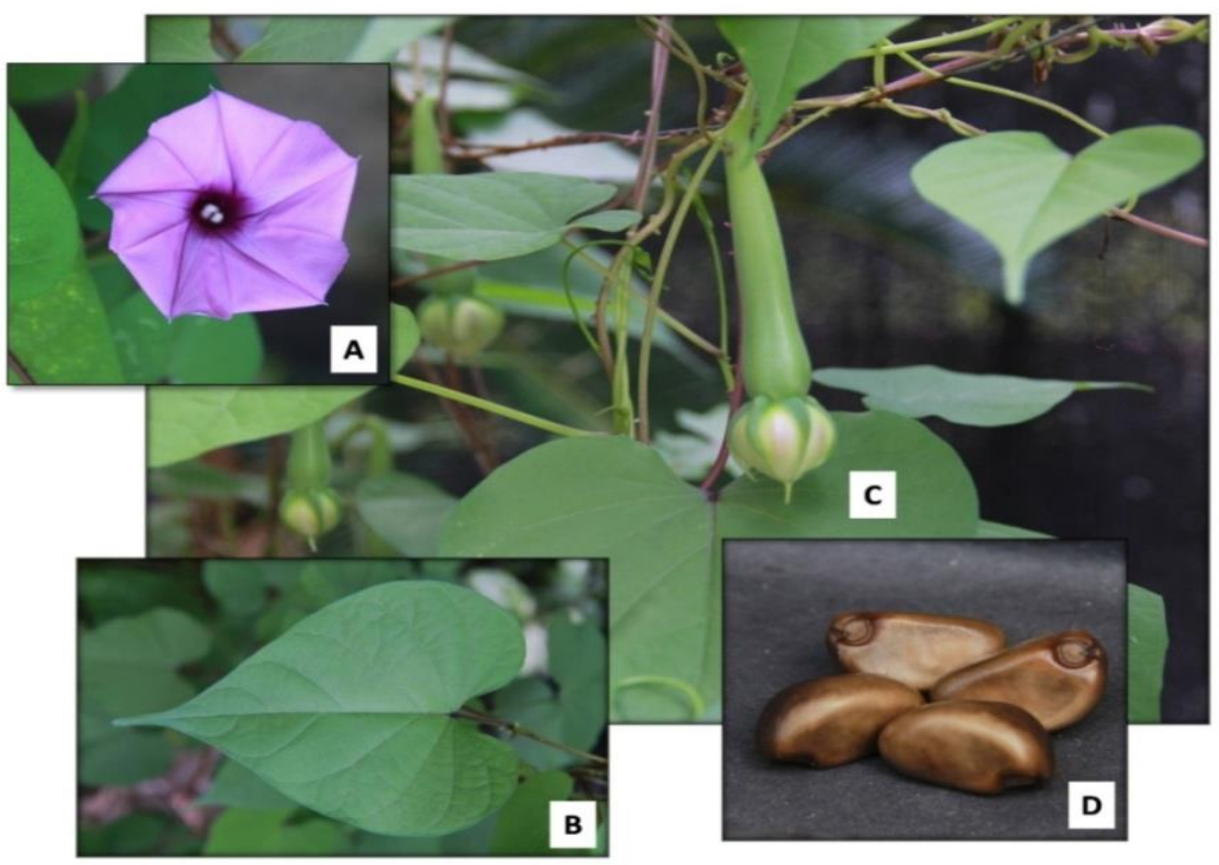

Plate 1: (A) Fully bloomed flower (B) fully developed leaf (C) vine and tender hypocarp with a true fruit, a capsule (D) fully matured seeds of clove bean (Ipomoea muricata)

\section{MATERIALS AND METHODS}

Three experiments were conducted to find out (i) the best storage period and storage condition for clove bean seeds, (ii) vegetative propagation from stem cuttings of clove bean and (iii) the effect of potting mixture and fertilizer type on growth and yield of clove bean. The study was conducted at the Department of Crop Science, Faculty of Agriculture, University of Ruhuna, from November 2020 to March 2021.

\section{Experiment 1:}

The first experiment was conducted to study the effect of two factors includes storage period and storage condition, and their interaction on seed germination of clove beans. Four storage periods (2, 4, 6 and 8 weeks after harvesting of seeds) and two storage conditions (room temperature $130{ }^{\circ} \mathrm{C}$ and cold storage under refrigerator/ $4^{\circ} \mathrm{C}$ ) were considered. Eight treatment combinations were laid out by using a factorial complete randomized design with three replicates while keeping five seeds per replicate. The seeds were covered by paper and stored separately under the dark condition at room temperature and refrigerator conditions for completion of the appropriate storage periods. After completion of the respective storage period, seeds were placed in plastic pots filled with washed-find sands. Watering was done to maintain the wet condition in sand media when necessary.

Germinations were recorded daily for up to two weeks. Seed with about $2 \mathrm{~mm}$ radicle were considered as a germinated seed. At the end of the germination period, final germination percentage (FGP; equation 1) and germination rate index (GRI; equation 2) were calculated using equations mentioned below (Aravind et al., 2019).

$$
\begin{array}{r}
F G P=\frac{\text { Number } \text { of germinated seeds }}{\text { Total number of seeds sown }} \times 100 \\
- \text { Equation (1) }
\end{array}
$$


$G R I=N 1 / T 1+N 2 / T 2+N 3 / T 3+\cdots+N n / T n$

- Equation (2)

$\mathrm{N} 1, \mathrm{~N} 2, \mathrm{~N} 3, \ldots \ldots, \mathrm{Nn}=$ number of germinated seeds at a time (days)

$\mathrm{T} 1, \mathrm{~T} 2, \mathrm{~T} 3, \ldots, \mathrm{Tn}=$ number of germinated seeds at a specific time (not the cumulative number).

\section{Experiment 2:}

The second experiment had two subexperiments. The first sub-experiment was set up to investigate the effect of the number of nodes per cutting (single node and double node), and the second subexperiment was conducted to evaluate the effect of presence and absence of a leaf or half leaf on rooting of cutting. Completely randomized design was used as an experimental design with four replicates for both sub-experiments. Five cuttings were considered as a replicate. Single propagators were used to establishing the cuttings filled with the potting mixture of topsoil: sand: coir dust: compost into 4:4:4:1 ratio. Three weeks after planting all cuttings were removed from propagators and the number of roots, length of the roots, "vigour" scale for root system (well distributed more than ten healthy roots $=$ 5 , more than ten weakly emerged roots $=$ 4 , five to ten healthy roots $=3$, less than five, weakly emerged roots $=2$, no roots only callus formation $=1$ ) and bud growth (newly emerged healthy and green colour bud with more than two leaves $=5$, newly emerged healthy and green colour bud with less than two without leaves $=4$, newly emerged healthy and green colour bud without leaves $=3$, newly emerged pale green colour bud with leaves $=2$, newly emerged pale green colour bud with leaves without leaves $=1$ ) were recorded. Length of the roots was measured manually using a ruler.

\section{Experiment 3:}

Two-factor factorial randomized complete block design was used to set up the third experiment with three replicates. The first factor of the experiment was different potting mixtures and the second factor was fertilizer type. Four potting mixtures (PM1topsoil: sand: compost 1:1:1, PM2- topsoil: sand: compost 2:1:1, PM3- topsoil: sand: compost 1:2:1, PM4- topsoil: sand: compost 1:1:2) and two fertilizer types (FT1- organic fertilizer, FT2- inorganic fertilizer) were used in the experiment. Therefore, eight treatment combinations and twenty-four experimental units were in this experiment. Treatment combinations were allocated randomly within the block. Seeds of the previous season stored in room temperature for two weeks were used for this study. Eight litres pots were used for the experiment.

Recommended fertilizer rate for tomato by Department of Agriculture (Urea, Triple super phosphate and Muriate of potash at the rate of 65,325 and $65 \mathrm{~kg} \mathrm{ha}{ }^{-1}$, respectively as the basal dressing and $65 \mathrm{~kg}$ $\mathrm{ha}^{-1}$ of Urea at 3 weeks after planting while $65 \mathrm{~kg} \mathrm{ha}^{-1}$ of each Urea and MOP at 6 weeks after planting) was used as inorganic fertilizer since the recommended fertilizer mixture is not available for clove bean in Sri Lanka. Based on the recommendation, nitrogen, phosphorous and potassium amount was calculated for the volume of the pot. Compost was used as the organic fertilizer and the amount of compost was calculated based on the availability of N\% in compost. The nitrogen $\%$ and moisture level of the compost were $0.8 \%$ and $40 \%$, respectively. Further, it was assumed that only $25 \%$ of the $\mathrm{N}$ in the compost is taken up by the crop. Accordingly, additional amount of compost (233 g per pot) was applied equivalent to $\mathrm{N}$ content calculated based on inorganic fertilizer recommendation. Three seeds per pot were placed and after two weeks of germination, two seedlings were removed from the pot by leaving a single plant per pot.

Irrigation was done immediately after seed sowing and thereafter as needed. During the 
vegetative stage, irrigation was done with two days interval while irrigation was done in every day during the flowering and pod bearing stage. Hand weeding was practiced when necessary. Pinching was done 20 days after seed germination to encourage axillary buds formation. As a result of pinching many side branches may rise from the stem of the main vine and increase the production. Clove bean pods were harvested seven days after pod set. The pods become soft when they touched at harvest as a vegetable. Harvesting was started about 50-60 days after seed sowing and continued with two days interval up to three months. All pods were separated into two parts as edible and the non-edible portions. After that both portions were oven-dried to obtained dry weight at $80^{\circ} \mathrm{C}$ for 72 hours.

The average length of the pod, the average circumference of the pod, number of pods per vine, fresh weight of the edible and nonedible portion of the pods, dry weight of the edible and non-edible portion of the pods, total above-ground dry biomass per vine, root dry weight per vine and shoot to root ratio per vine were taken as yield parameters. Measured parameters related to the pod are shown in the Plate 2.

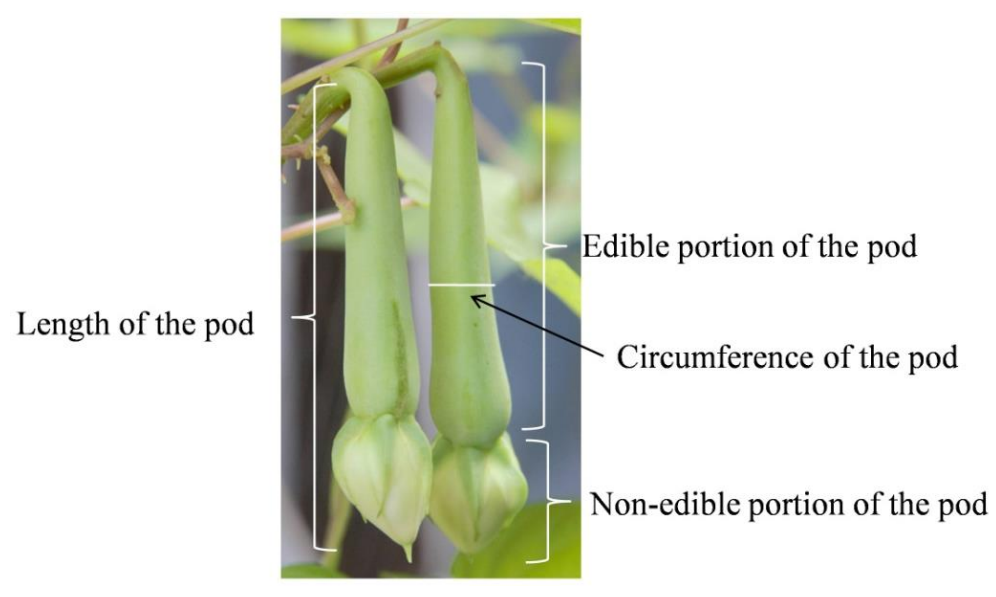

Plate 2: Pod of clove bean with different parameters

\section{Data analysis}

The data were analyzed using statistical software of SAS and Minitab 17. ANOVA appropriate to the experiment design was performed. The Duncan Multiple Range Test at the probability of $5 \%$ was used to compare means. Descriptive data were presented using graphs in MS Excel.

\section{RESULTS AND DISCUSSION}

The final germination percentage and germination rate index of the first experiment were not significantly affected by the interaction between storage duration and the condition. However, the final germination percentage and germination rate index were significantly different between storage conditions while the highest values were recorded when storing seeds under room temperature (Figure 1A and 1B). Research findings related to clove bean seeds storage is not available at the moment. Though, Pradhan and Badola (2012) found that when stored seeds of Swertia chirayita, a critically endangered medicinal plant in Himalaya, at $4^{\circ} \mathrm{C}$ recorded the low mean germination percentage and high seed germination throughout the storage period of 24 months. Whereas, speed and vigour index of germination over six months of storage was not significantly different between two storage conditions of cold room and dry storage (room temperature) for two medicinal plant species of Eruca sativa 
Lam. and Anthemis altissima L. (Alizadeh and Isavand, 2004). In the present study, it was observed that clove bean seeds germinate just after harvesting. Hence, it does not have dormancy. Further, it can be suggested that clove bean seeds

A

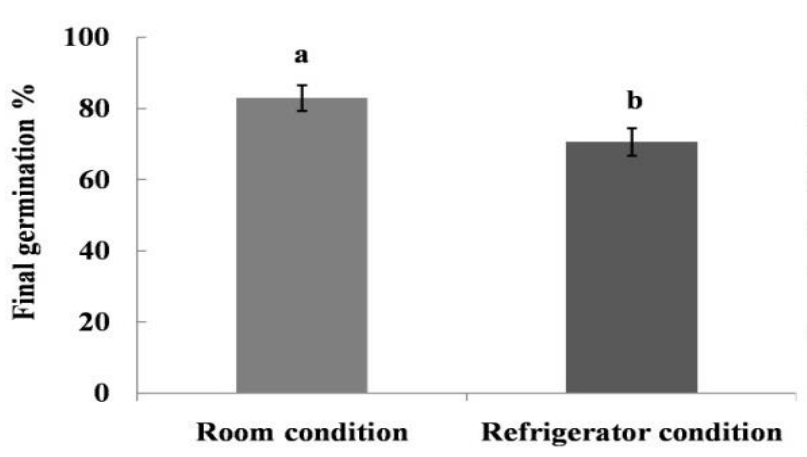

contain enough storage food for early seedling growth due to its large seed size. Therefore, further study would be needed to determine the effect of storage condition on germination matrix over a long time.

B

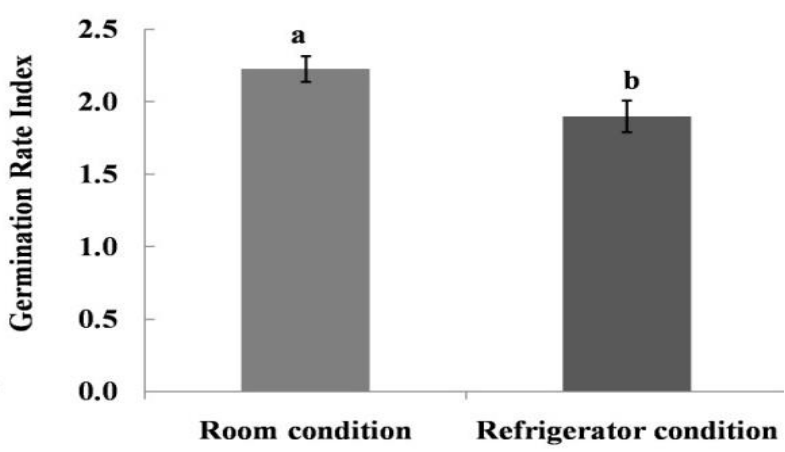

Figure 1: Effect of storage conditions of the clove bean seeds on (A) Final germination percentage $(\mathrm{p}<0.05)$ and (B) germination rate index $(\mathrm{p}<0.001)$. Means of the columns with the same letters are not significantly different at $\alpha=0.05$. The standard error of the mean is indicated by error bars

According to the results of the two subexperiments of the second experiment, the number of roots, total root length, vigour of the roots and vigour of the new buds formed were not significantly different between treatments. Therefore, a single node or double nodes with presence or absence of a leaf or half leaf could be used to propagate stem cuttings of the clove bean successful. Plate 3 shows the rooting of stem cuttings of a single node with full leaf (3A), a single node with half leaf (3B) and double nodes with half leaf (3C).
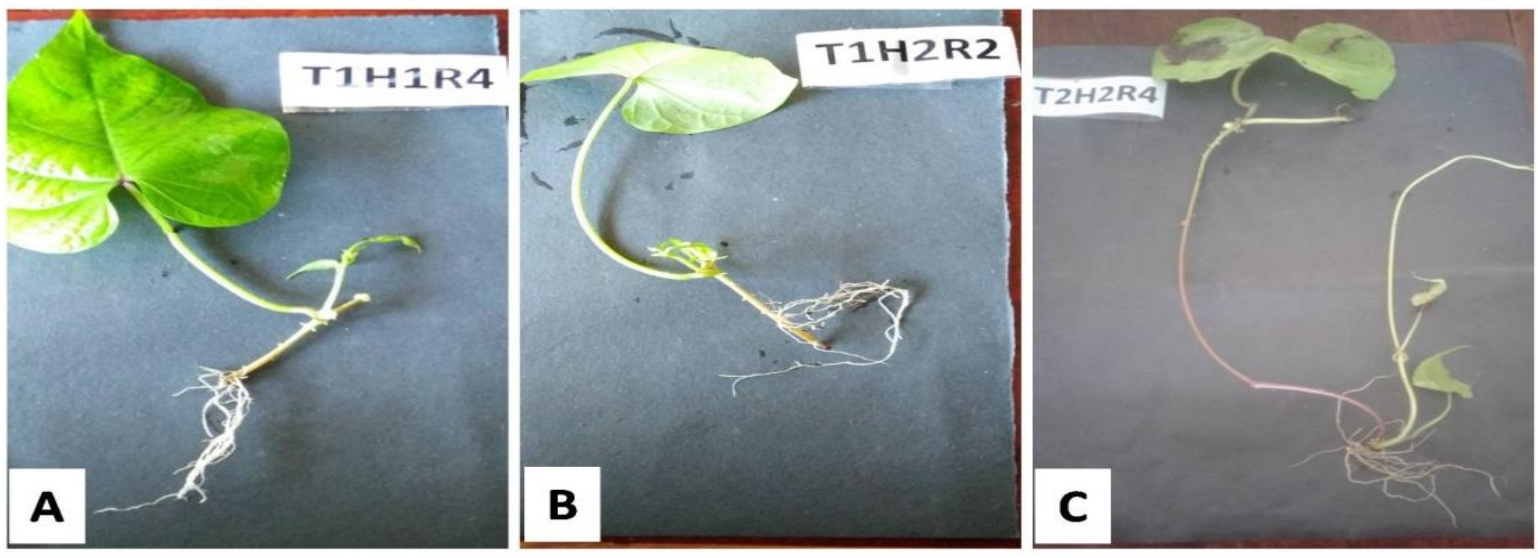

Plate 3: Rooting of stem cuttings of (A) single node with full leaf (2B) single node with half leaf and (2C) double nodes with half leaf three weeks after establishment in single propagator

The average length and the circumference of the pods harvested in the third experiment were affected neither by the interaction (PM x FT) nor the main factors of potting mixture and fertilizer type. The average length and circumference of the 
clove bean pod were $8.35 \mathrm{~cm}$ and $3.45 \mathrm{~cm}$, respectively. The number of pods per vine, fresh and dry weight of the edible and nonedible portions of the pod, total aboveground dry weight per vine, root dry weight per vine and shoot to root ratio were not significantly influenced by PM x FT. However, the number of pods per vine was significantly different among potting mixtures $(p<0.05)$ and fertilizer types $(\mathrm{p}<0.05)$ (Figure 2). The highest number of pods per vine was recorded in PM1 which was not significantly different from PM3 and PM4. However, the significantly lowest number of pods per vine was reported by PM2. Furthermore, the greatest number of pods per vine was produced when applying organic fertilizer than inorganic fertilizer.
A

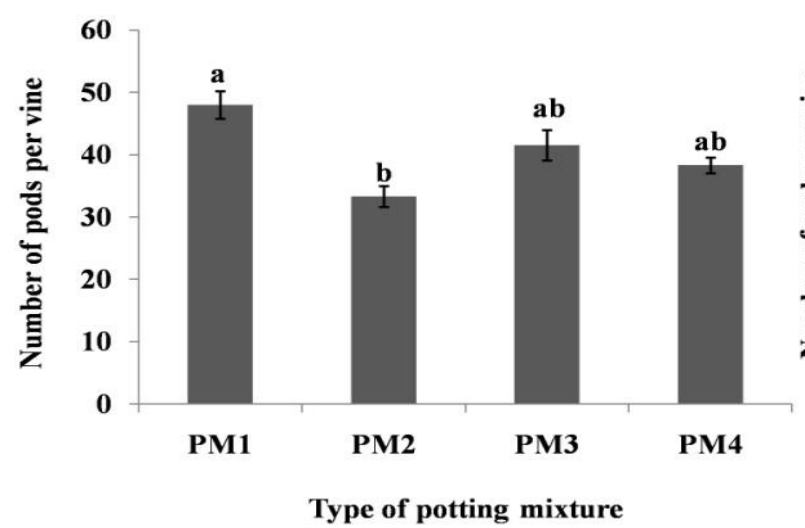

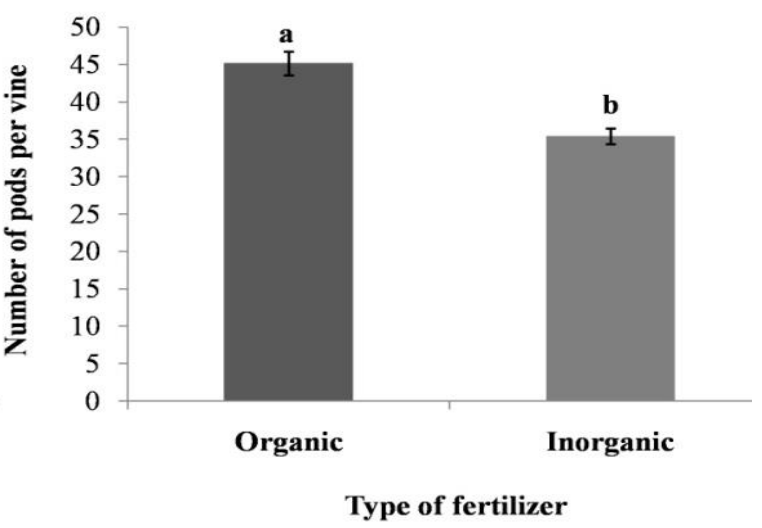

Figure 2: Number of pods per vine as affected by $(A)$ potting mixture $(\mathrm{p}<0.05)$ and $(B)$ fertilizer type $(\mathrm{p}<0.05)$. PM denoted by potting mixture; PM1- Topsoil 1: sand 1: compost 1, PM2- Topsoil 2: sand 1: compost1, PM3- Topsoil 1: sand 2: compost 1, PM4- Topsoil 1: sand 1: compost 2. Means of the columns with the same letters are not significantly different at $\alpha=0.05$. The standard error of the mean is indicated by error bars

The fresh weight of the edible portion was significantly different among potting mixture $(\mathrm{p}<0.01)$ and fertilizer type $(\mathrm{p}<0.01)$. The highest value was recorded in PM1. Though, it was not significantly different from PM3. The lowest fresh weight of the edible portion of the pod was recorded in PM2 and PM4. Significantly high fresh weight of the edible portion of the pod was produced when applied organic fertilizer compared to inorganic fertilizer (Table 1). Only potting mixture significantly influenced the fresh weight of non-edible portion $(\mathrm{p}<0.01)$ where the highest value was recorded in PM1 mixture and the lowest value was recorded in PM2. Depending on the availability, different materials are used to prepare potting mixtures and growing media worldwide (Schmilewski, 2009). However, all potting media should provide sufficient aeration and water to plant while providing physical support to the plant through optimizing root growth. Therefore, pore spaces between particles are essential and controlled by the size of the particles (Bilderback et al., 2005). According to the results of the present study plants performed well under PM1 potting mixture which is prepared by mixing topsoil 1: sand 1: compost 1 . It is might be due to good drainage, aeration and nutrient availability of the mixture which is favorable for root growth of clove bean plant. Grunert et al. (2008) mentioned that quality and the quantity of the vegetable production are influenced by physio-chemical properties of the growing media and the growing techniques including fertigation. On the other hand, it seems that the increased 
proportion of compost in PM4 did not enhance the performances of the crop.

The dry weight of the edible portion was significantly different among potting mixture $(\mathrm{p}<0.01)$ and fertilizer type $(p<0.01)$. The greatest dry weight of edible portion was reported at PM1 when applied organic fertilizer. However, dry weight of non-edible portion was only affected by fertiliser type $(\mathrm{p}<0.01)$ where the highest value was recorded in organic fertilizer applied plants. Dry weight of total aboveground biomass was significantly different among potting mixtures $(\mathrm{p}<0.05)$ and fertilizer type $(\mathrm{p}<0.05)$. The significantly higher total above-ground dry biomass production was recorded in PM1 and all other potting mixtures reported lower values (Table 1). As same as previous parameters organic fertilizer significantly influenced the total above-ground dry biomass production of clove bean (Table 1). This may be due to the improvement of physical properties of the potting mixture and slow release of nutients by organic fertilizer. However, Ndor et al. (2013) suggested that combine application of $40 \mathrm{~kg} / \mathrm{ha}$ of urea and $5 \mathrm{t} / \mathrm{ha}$ of poultry manure as organic fertilizer enhanced the production of fluted pumpkin (Telfairia occidentalis Hook F.) in Nigeria. Elsewhere, it was reported that the highest seed yield, oil yield and fruit yield of medicinal pumpkin (Cucurbita pepo subsp. Pepo convar. pepo var Styriaca) were resulted when inoculated seeds with phosphate solubilizing bacteria together with free-living nitrogen fixing bacteria and supply $50 \%$ of nutrients by organic fertilizer (Habibi et al., 2011). Furthermore, integrated plant nutrient management through inorganic fertilizer, vermicompost and bio-fertilizer recorded the highest number of fruits per plant, fruit weight, fruit girth and yield of bitter gourd (Momordica charantia) (Thriveni et al., 2015). Therefore, it can be suggested that combine application of inorganic and organic fertilizer including vermicompost would improve the growth and yield of clove bean. Further studies are needed to study the effect of integrated plant nutrient management for clove bean. Root dry weight and shoot to root ratio was not significantly different among treatments in the present study.

Table 1: Fresh weight of edible and non-edible portions of the pod, dry weight of edible and non-edible portions of the pod and total above-ground dry biomass per vine with standard error of the means for potting mixtures and fertilizer types in the third experiment

\begin{tabular}{lrrrrr}
\hline Treatment & $\begin{array}{c}\text { Fresh weight } \\
\text { of edible } \\
\text { portion }(\mathrm{g})\end{array}$ & $\begin{array}{c}\text { Fresh weight } \\
\text { of non-edible } \\
\text { portion }(\mathrm{g})\end{array}$ & $\begin{array}{c}\text { Dry } \\
\text { weight of } \\
\text { edible } \\
\text { portion }(\mathrm{g})\end{array}$ & $\begin{array}{c}\text { Dry } \\
\text { weight of } \\
\text { non-edible } \\
\text { portion }(\mathrm{g})\end{array}$ & $\begin{array}{c}\text { Total above- } \\
\text { ground dry } \\
\text { biomass }(\mathrm{g})\end{array}$ \\
\hline PM1 & & & & & \\
PM2 & $92.42^{\mathrm{a}} \pm 16.29$ & $74.15^{\mathrm{a}} \pm 11.57$ & $6.89^{\mathrm{a}} \pm 1.62$ & $6.61^{\mathrm{a}} \pm 1.25$ & $43.78^{\mathrm{a}} \pm 2.76$ \\
PM3 & $47.16^{\mathrm{b}} \pm 8.32$ & $34.79^{\mathrm{b}} \pm 5.37$ & $3.08^{\mathrm{b}} \pm 0.46$ & $4.22^{\mathrm{a}} \pm 0.77$ & $35.48^{\mathrm{b}} \pm 3.43$ \\
PM4 & $68.48^{\mathrm{ab}^{\mathrm{b}} \pm 10.57}$ & $53.57^{\mathrm{a}} \pm 6.47$ & $4.05^{\mathrm{b}} \pm 0.63$ & $5.71^{\mathrm{a}} \pm 0.78$ & $34.93^{\mathrm{b}} \pm 2.91$ \\
\hline P value (PM) & $48.82^{\mathrm{b}} \pm 5.67$ & $35.57^{\mathrm{b}^{\mathrm{b}} \pm 4.60}$ & $3.22^{\mathrm{b}} \pm 0.40$ & $4.24^{\mathrm{a}} \pm 0.45$ & $36.54^{\mathrm{b}} \pm 6.32$ \\
\hline FT1 (organic) & $<6.01$ & $<0.01$ & $<0.01$ & $>0.05$ & $<0.05$ \\
\hline FT2 (inorganic) & $51.52^{\mathrm{b}} \pm 5.83$ & $39.42^{\mathrm{a}} \pm 6.13$ & $3.21^{\mathrm{b}} \pm 0.32$ & $4.19^{\mathrm{b}} \pm 0.50$ & $33.01^{\mathrm{b}} \pm 1.72$ \\
\hline P value (FT) & $<0.01$ & $>0.05$ & $<0.01$ & $<0.01$ & $<0.05$ \\
\hline CV\% & 12.63 & 11.65 & 11.95 & 14.45 & 12.08 \\
\hline
\end{tabular}

Remarks: $\mathrm{PM}=$ potting mixture, $\mathrm{FT}=$ Fertilizer type, $\mathrm{CV}=$ coefficient of variation. Mean values followed by the same letters are not significantly different at $\alpha=0.05$ 


\section{CONCLUSIONS}

According to the results of the present study it can be conclude that store seeds of clove bean for two months, without affecting germination significantly, are possible under room temperature. Furthermore, clove bean can be propagated vegetatively using stem cutting of single or double nodes with leaf, half leaf or without leaf. Moreover, high clove bean yield could be obtained by applying organic fertilizer into the potting mixture prepared with equal proportions of topsoil, sand and compost.

\section{REFERENCES}

Abdulkadyrova, M.A., Dikinov, A.H., Tajmashanov, H.È., Shidaev, L.A. and Shidaeva, E.A. (2016). Global Food Security Problems in the Modern World Economy. International Journal of Environmental and Science Education. 11(12): 5320-5330

Alizadeh, M. and Isavand, H.R. (2004). Evaluation and the study of germination potential, speed of germination and vigor index of the seeds of two species of medicinal plants (Eruca sativa Lam. and Anthemis altissima L.) under cold room and dry storage condition. Iranian Journal of Medicinal and Aromatic Plants. 20(3): 301307.https://www.sid.ir/en/journal/100589.

Aravind, J., Vimala Devi, S., Radhamani, J., Jacob, S.R. and Srinivasan, K. (2019). The germinationmetrics package: A brief Introduction. ICAR-National Bureau of Plant Genetic Resources. New Delhi, India:46

Bilderback, T. E., Warren, S. L., Owen Jr. J. S., and Albano, J. P. (2005). Healthy substrates need physicals too! HortTechnology. 15: 747-751.

Bursać Kovačević, D., Brdar, D., Fabečić, P., Barba, F. J., Lorenzo, J. M., and Putnik, P. (2020). Strategies to achieve a healthy and balanced diet: fruits and vegetables as a natural source of bioactive compounds. Agri-Food Industry Strategies for Healthy Diets and Sustainability, 51-88. https://doi.org/10.1016/B978-0-12817226-1.00002-3

Bvenura, C. and Sivakumar, D. (2017). The role of wild fruits and vegetables in delivering a balanced and healthy diet. Food Research International. 99:15-30. doi:10.1016/j.foodres.2017.06.046

Cui, K. and Shoemaker, S.P. (2018). A look at food security in China. npj Science of Food. 2,4. https://doi.org/10.1038/s41538018-0012-x

Ezeh, A. C., Bongaarts, J., and Mberu, B. (2012). Global population trends and policy options. The Lancet, 380(9837): 142-148. doi:10.1016/s0140-6736(12)60696-5

Grunert, O., Perneel, M., and Vandaele, S. (2008). Peat-based organic grow bags as a solution to the mineral wool waste problem. Mires and Peat. 3:1-5. http://www.miresand-peat.net/, ISSN 1819-754

Habibi, A., Heidari, G., Sohrabi, Y., Badakhshan, $\mathrm{H}$. and Mohammadi, K. (2011). Influence of bio, organic and chemical fertilizers on medicinal pumpkin traits. Journal of Medicinal Plants Research. 5(23): 5590-5597. http://www.academicjournals.org/JMPR

Jena, A.K., Deuri, R., Sharma, P. and Singh, S.P. (2018). Underutilized vegetable crops and their importance. Journal of pharmacognosy and phytochemistry. 7(5): 402-407.

Malasawmkimi, S.J. and Markose, B.L. (2008). Genetic variability in clove bean (Ipomoea muricata (L.) Jacq.). Vegetable Science. 53(2): 192-193.

Ndor, E., Dauda, S. N. and Garba, M. N. (2013). Growth and Yield Performances of Fluted Pumpkin (Telfairia occidentalis 
Hook F.) under Organic and Inorganic Fertilizer on Ultisols of North Central Nigeria. International Journal of Plant \& Soil Science. 2(2): 212-221.

Parisa, D., Surendra, M., Janani, $\mathrm{P}$ and Gurung, N. (2019). Clove bean (Ipomoea muricata): A popular vegetable of Kerala. Kerala Karshakan e-Journal. Pp 18-19.

Pradhan, B.K. and Badola, H.K. (2012). Effect of Storage Conditions and Storage Periods on Seed Germination in Eleven Populations of Swertia chirayita: A Critically Endangered Medicinal Herb in Himalaya. The Scientific World Journal. Article ID 128105 , https://doi.org/10.1100/2012/128105

Schmilewski, G. (2009). Growing medium constituents used in the EU. Acta Horticulturae. 819: 3345.
Thriveni, V., Mishra, H.N., Pattanayak, S. K., Sahoo, G. S. and Thomson, T. (2015). Effect of inorganic, organic fertilizers and biofertilizers ongrowth, flowering, yield and quality attributes of bitter gourd, Momordica charantia L. International Journal of Farm Sciences. 5(1): 24-29.

Wallace, CA., Sperber, W.H. and Mortimore, S.E. (2010). Food Safety for the 21st Century: Managing HACCP and Food Safety throughout the Global Supply Chain. John Wiley \& Sons.

Weisfeld-Adams, E. and Andrzejewski, A. (2008). Hunger and Poverty: Definitions and distinctions. The hunger project. 5, Union Square West New York, NY 10003.https://pdf4pro.com/amp/view/hung er-and-poverty-definitions-and-distinctions -24f53.html. 